\title{
Information technology studies in higher business and management education in Finland
}

\author{
Paturi T. \\ Helsinki Business Polytechnic \\ Rautatieläisenkatu 5, 00520 Helsinki, Finland \\ tel: 358-0-14890282, fax: 358-0-147063 \\ e-mail: Tuulikki.Paturi@atki.helbp.fi
}

\begin{abstract}
This paper explains the structure of higher business and management education in Finland and especially the amount and nature of information technology studies in the syllabuses.

Keywords

Higher business and management education, Information technology education.
\end{abstract}

\section{INTRODUCTION}

This study examines the post-secondary level programmes for business expertise offered in Finland by universities and the new polytechnics.

An extensive change is under way in the structure of post-secondary education. The level of the degrees in secondary education will be upgraded to better correspond to the European degrees, and the polytechnics are being developed as an alternative to universities.

Figure 1 illustrates the structure of the Finnish degree system. The comprehensive school is compulsory for all children. The comprehensive school leads to either a 3-year high-school or a vocational school. Higher education is provided by universities, polytechnics, and vocational collages.

The extent of the studies is measured in credits. A credit is the term used to refer to a student's 40-hour study effort including classes, exercises, seminars, both supervised and selfdirected learning. Full-time students can successfully take 40 credits per year. (OPH, 1994). 


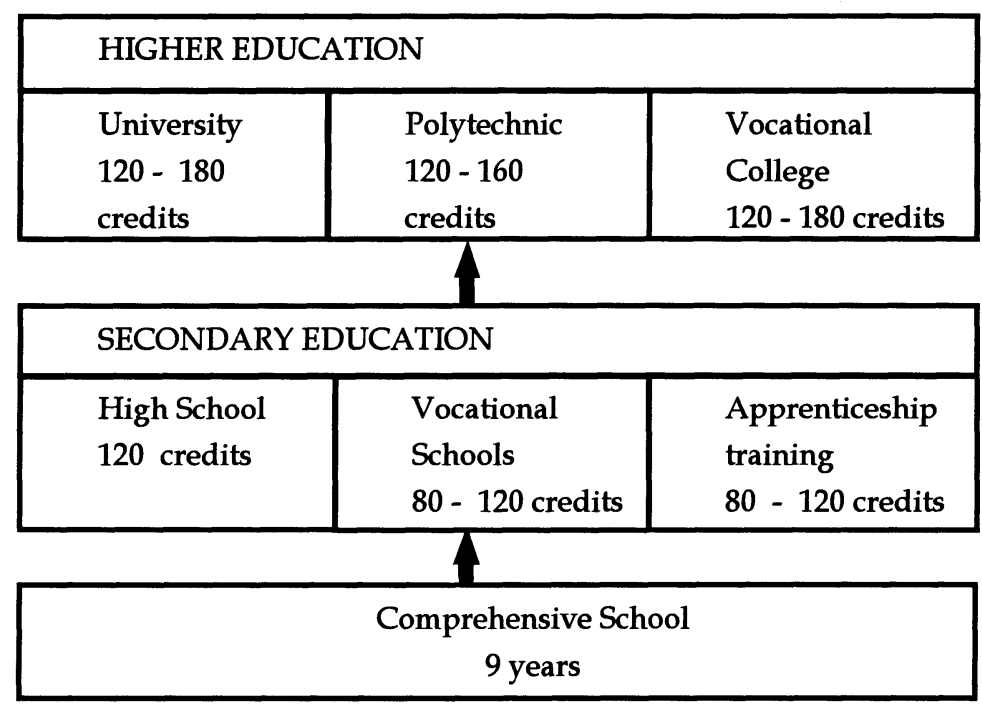

Figure 1. The Finnish degree system.

This thesis examines information technology studies in higher business and management education in universities and polytechnics.

\section{POST-SECONDARY BUSINESS STUDY PROGRAMMES}

\subsection{The Undergraduate Programmes in Business Studies}

Ten universities and fifteen polytechnics offer undergraduate programmes for students who want to specialise in business management and expertise.

The universities offer a 120-credit B.B.A. degree programme, a 160-credit M.B.A. programme and the post-graduate level Licentiate and Doctorate programmes. A Licentiate thesis and/or a Doctoral dissertation are required.

The polytechnics offer a 140 -credit programme leading to a Business Polytechnic degree (the Finnish title 'tradename').

The B.B.A. degree can be taken in three years, the Business Polytechnic degree in three and a half years, and the M.B.A. degree in four years. In practice, university undergraduates graduated in 5.5 years in 1994. The first students from polytechnics graduated in 1995 which means that no statistical figures are yet available concerning the length of study time. It seems to be the tendency that 3.5 - 4 years are required to finish the studies. The Polytechnics Act declares the maximum length of studies to be 4.5 years. (OPM, 1996). 


\subsection{The Structure of the Study Programmes}

In universities the study programmes are divided into basic studies, subject studies, and advanced studies. In polytechnics they are divided into basic studies, professional studies and training. The basic studies are obligatory for all students and they usually include language and methodology studies. The subject studies and the professional studies contain both compulsory and optional study units.

The Business Polytechnic Degree includes a compulsory 20-credit training, whereas the length of training in the B.B.A. or M.B.A. degrees is maximum 6 credits. All the business degrees include a compulsory thesis or diploma project: a 20 credit thesis for the M.B.A. degree, a 10-credit diploma project, or a vocationally-oriented thesis for the Business Polytechnic degree.

All degree programmes include a maturity test to prove that graduate has a good command of his/ her study language, Finnish or Swedish (in most cases also the mother tongue of the student). (OPM, 1996).

\begin{tabular}{|c|c|c|}
\hline \multicolumn{3}{|c|}{ Thesis or diploma project } \\
\hline $\begin{array}{l}\text { Advanced } \\
\text { subject studies }\end{array}$ & $\begin{array}{l}\text { optional } \\
\text { study units }\end{array}$ & Training \\
\hline \multicolumn{2}{|c|}{$\begin{array}{l}\text { Subject studies } \\
\text { Professional studies }\end{array}$} & $\begin{array}{l}\text { optional } \\
\text { subject studies }\end{array}$ \\
\hline Basic studies & $\begin{array}{l}\text { Language } \\
\text { studies }\end{array}$ & $\begin{array}{l}\text { Methodology } \\
\text { studies }\end{array}$ \\
\hline
\end{tabular}

Figure 2. The Structure of the Study Programmes.

\section{THE CONTENTS OF THE STUDY PROGRAMMES}

This paper takes a special interest in the extent of Information Technology (IT) studies in the business programmes. The syllabuses have been analysed and the number of credits has been grouped as follows:

- the number of credit per compulsory subjects

- the number of credits per compulsory Information Technology Studies

- the number of credits per optional studies.

Both university and polytechnic programmes offer their respective subject study lines for the following fields:

- Management and organisations

- Accounting and Finance

- Marketing and Delivery

- Social and Economic tasks

- Services and Enterprising. 
In addition to subject studies in business, the compulsory study units include such methodological studies as mathematics, statistics, and data processing, which can best be classified as general studies.

All programmes contain studies in the mother tongue, the second official language, and at least one foreign language. A graduate must fulfil the language requirements for civil servants in a bilingual country as stated in the Finnish law. Additionally, the student is required to show verbal and reading comprehension skills in at least one foreign language.

A summary of the number of compulsory and optional credits required is provided in the figures below. Figure 3 illustrates the required credits for university degrees and figure 4 the credits for polytechnic studies.

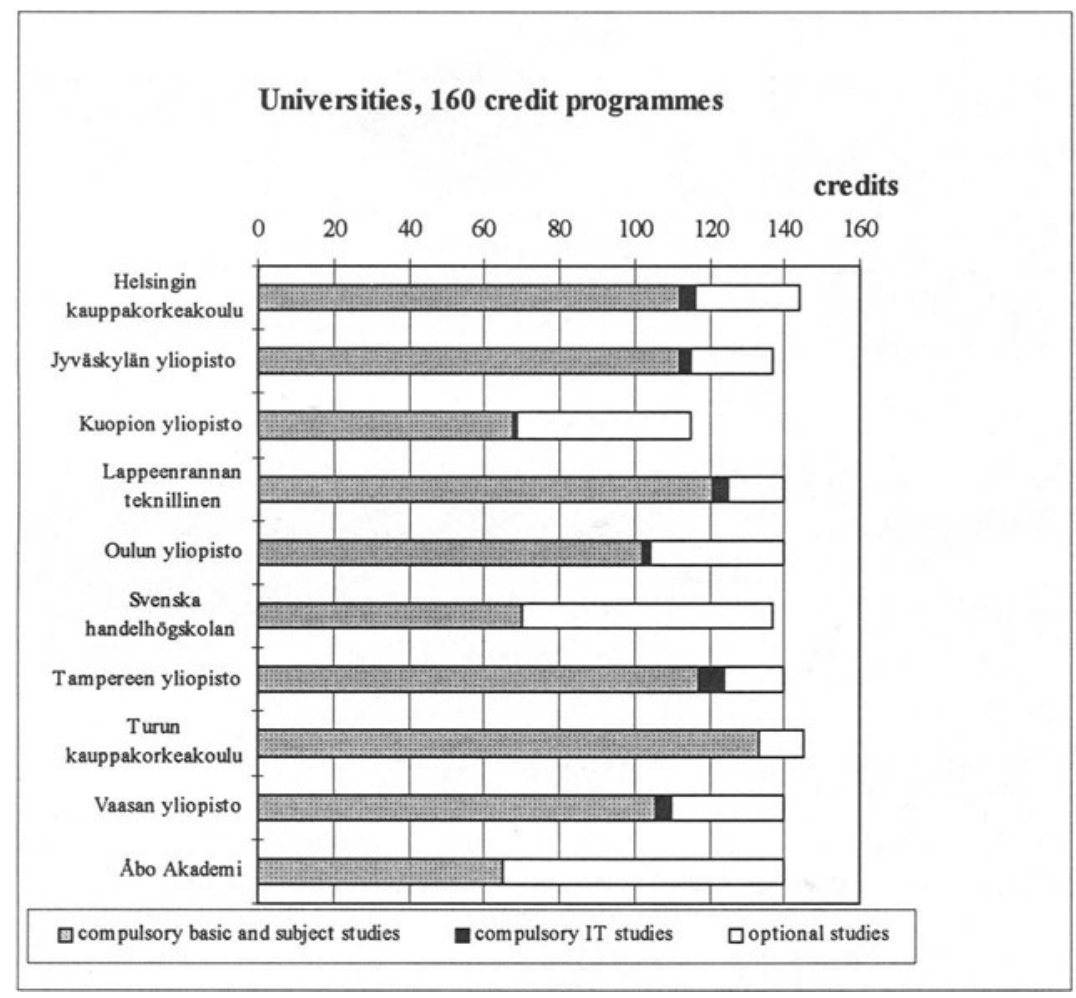

Figure 3. The distribution in compulsory and optional credits in universities. 


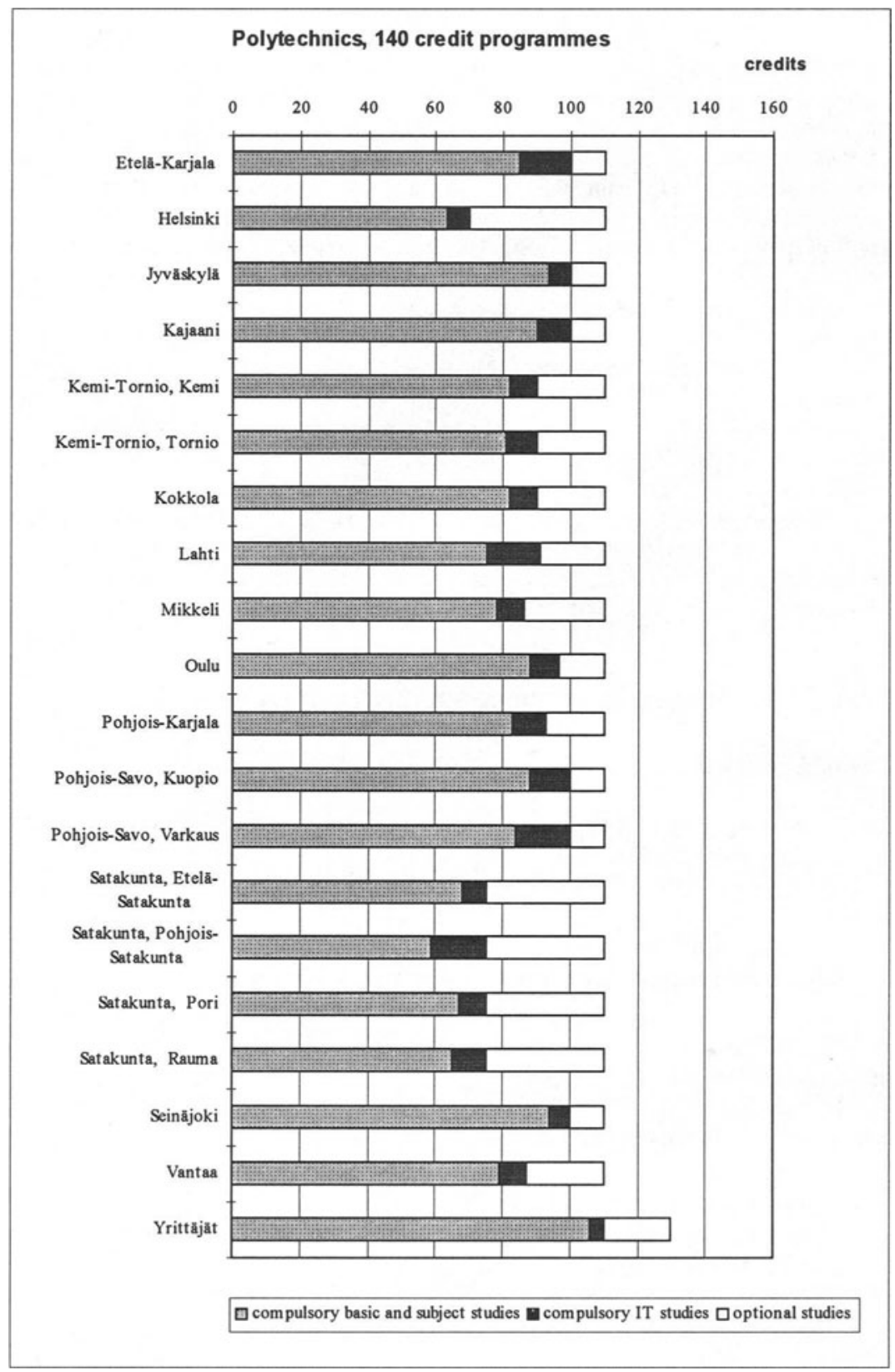

Figure 4. The distribution in compulsory and optional credits in polytechnics. 
In polytechnics, the compulsory credit courses constitute 50-71 percent of the degree programme, the average being 64 percent. For information technology courses the figures are $4-21$ percent, average 11 percent. The corresponding figures in universities are as follows: compulsory credit courses $31-83$ percent, out of which information technology courses $0-6$ percent, average 2 percent.

The figures above indicate that the share of compulsory studies is equally large in both universities and polytechnics, namely 65 percent. However there is a clear difference when we consider the IT credit studies offered: in the average polytechnics offer 10 compulsory credit courses ( 11 percent of the total) and universities 3 compulsory credits ( 2 percent of the total).

In polytechnics optional studies can make up $7-29$ percent ( 15 percent average) of the total, i.e. the students may take $10-40$ optional credits ( 21 in average). The corresponding figures in universities are $8-47$ percent ( 23 percent average), and $12-75$ credits ( 35 credits in the average).

The polytechnics offer $2-47$ optional IT credits, average 13. Not all polytechnics are alike in this respect, however. The polytechnics with an IT Study Programme offer a larger number of optional courses.

In universities undergraduates usually choose courses in the minor subjects as their optional studies. It is possible to study IT as a minor subject in all universities, consequently IT studies may constitute up to 47 percent of the degree studies. Even the average figures exceed the corresponding figures in polytechnics. (Study Guide).

\section{STUDIES IN INFORMATION TECHNOLOGY}

\subsection{Compulsory Study Units}

To describe the variety of compulsory studies in information technology, the names of study units are listed below and classified in major groups.

\section{Polytechnics}

In the field of basics of IT and hardware can be found the following courses:

- personal data processing (1,3 and 4 credits) in three schools

- the Basics of DP (2, 3 or 4 credits) in five schools

- Information Technology (4 credits)

- IT support (4 credits)

- the Basics of IT (1 or 2 credits) in two schools.

The field of applied IT includes these courses:

- IT in Business Solutions (2 credits)

- IT in Business and Society ( 2 credits) in two schools

- Office Technology, Office Automation (2 and 3 credits) in three schools.

- IT in Financial Management (2 credits)

- Information Systems (8 credits). 
The variety of application software is taught in the following courses:

- word processing ( 2 or 3 credits) in five schools

- the basics of WP and Office Automation ( 3 credits)

- Applications (1 credit)

- Applications, advanced course ( 2 credits).

Two polytechnics include systems development courses in their syllabuses

- Information Systems (3 credits)

- Information Systems Development (2 credits).

Even programming can be found as a compulsory course in one school:

- The Basics of Programming (1 credit).

\section{Universities}

In universities the corresponding compulsory study units were so few that they can be listed without classification into major groups as follows:

- IT tools for business administration graduates ( 0 credits)

- Personal data processing ( 2 credits)

- an introduction to data processing ( 2 or 3 credits) in two universities

- Computer-aided business development (4 credits)

- Get to Know your Computer (1 credit)

- A Computer as a Tool ( 2 credits)

- the Basics of IT ( 2 credits). (Study Guide).

\subsection{Optional study units}

The M.B.A Degree includes at least 15 credit studies in an optional minor subject. This can for instance be information technology, which is highly recommended by the business community. Unfortunately the courses in information technology are usually IT theory oriented. Therefore some universities offer business oriented information technology studies like Information Systems Development, Marketing Research and Information Systems, Executive Information Systems, Accounting and Finance Information Systems. The extent of these courses is usually $2-5$ credits.

The polytechnics offer more applied optional courses in information technology. They are for instance Desk Top Publishing, Computer Networks in Business, advanced courses in word processing or spreadsheet applications, a variety of marketing, accounting and logistic information systems, data bases and data management, even courses in programming. The extent of these courses is usually $2-3$ credits. (Study Guide).

\section{AN APPRAISAL OF THE ADEQUACY OF IT STUDIES}

The number and scope of computer-based information systems in business is increasing. Active employment of IT is a prerequisite for the successful management of business expertise. The CEOs must understand the role of IT and data processing in their business strategies. The middle management and business experts must be well versed in the application of information systems in their particular fields. 
Consequently, the education of managers and business experts must meet the needs of providing adequate means for understanding the impact of IT on one hand, and offering the required skills for using IT tools an the other.

In the Education, training and research in the information society published by the Ministry of Education as a national strategy it is stated that basic IT skills should be taught at all school levels, starting from comprehensive schools. These basic skills include the basics of IT, data management, and communication. (www).

It is also important to assertion that the students in vocational schools and polytechnics acquire the knowledge for applying these basic skills in the ever changing working environment.

At the moment the number of compulsory IT credits in the business and management programmes is at most 16 in polytechnics, which is equivalent to 6 months of study. In universities the corresponding figures are at most 7 credits, and less than 2 months. It is obvious and widely understood that restricting to only compulsory studies is not sufficient for a future professional in the information society. Therefore it is fortunate that the demands of the business community has directed the students to choose studies in information technology to increase their expertise.

\section{REFERENCES}

(OPM, 1996) Opetusministeriö: Yliopisto-opinnot 1996-1997 (Ministry of Education: University Education 1996-1997). Oy Edita Ab. Helsinki 1996.

(OPH, 1994) Opetushallitus: Koulutusopas 1995 (National Board of Education: Degree Programme Guide 1995). Painatuskeskus Oy. Helsinki 1994.

(Study Guide) Study guides 1995-1996 for each business and management degree programme. Total of 25.

(www) Ministry of Education: Education, training and research in the information society. http://www.minedu.fi/infostrategy.html. May 1996. 